BIP: Jurna Bahasa Indonesia Prima,

Vol 3, No. 1, 2021, Maret 2021, pp.

\title{
MODEL PENDIDIKAN KARAKTER BERBASIS IDEOLOGI LIMA-I DI PERGURUAN TINGGI STUDI PADA MAHASISWA S1
}

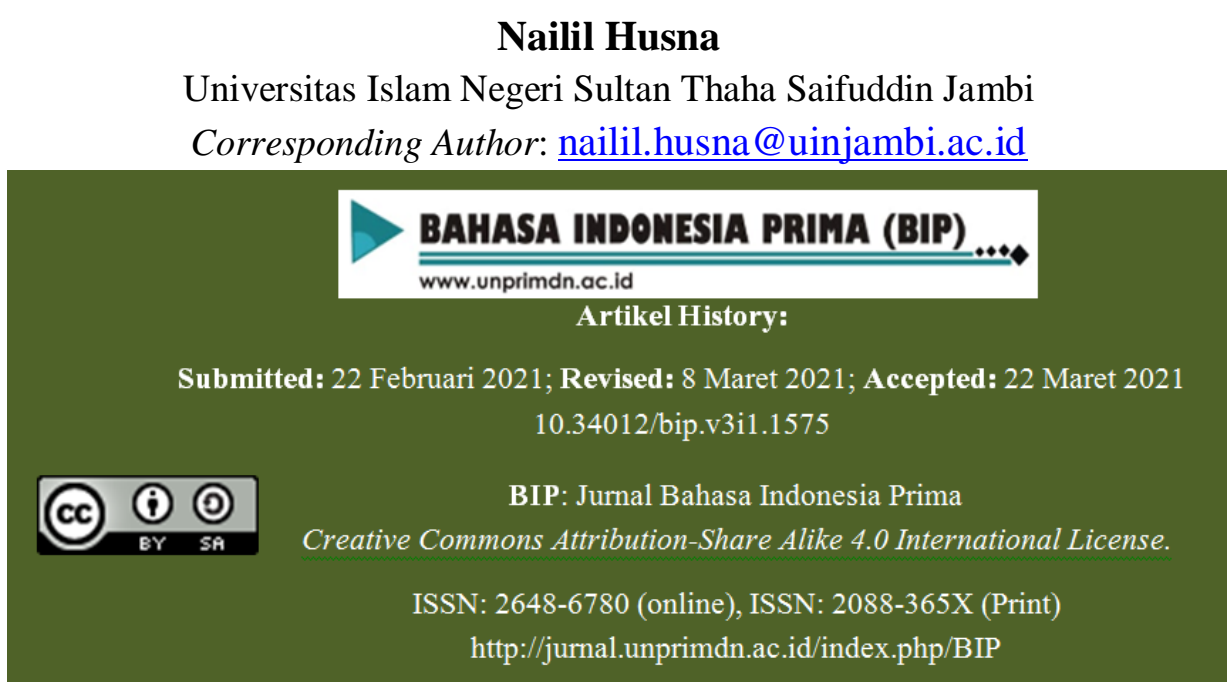

Abstrak: Dekadensi moral di kalangan mahasiswa saat ini cukup memprihatinkan karena mereka adalah agen perubahan menuju masa depan yang lebih baik. Perubahan itu sendiri adalah sesuatu yang mutlak dan pasti akan terjadi. Dengan demikian mahasiswa diharapkan menjadi pencipta ide-ide yang dihadirkan dalam bentuk pemikiran yang teratur dan sesuai dengan hakikat keilmuan yang dilandasi oleh karakter sebagai hasil dari proses pembelajaran di kampus. Namun, pembelajaran berbasis karakter saja tidak akan menjamin peningkatan moral. Alhasil, pengaplikasiannya membutuhkan pondasi yang kuat. Ideologi lima-i mensinergikan dan mensinkronisasikan energi yang ada antara peserta didik, lingkungan, dan tenaga pendidik menjadi energi pembelajaran dalam situasi pendidikan yang bersemangat, efektif, dan efisien untuk meningkatkan harkat dan martabat manusia. Model pendidikan karakter berbasis lima-i diharapkan dapat meningkatkan kualitas pembelajaran, diantaranya adalah karakter yang baik yang meliputi motivasi belajar siswa, kejujuran, kemandirian, disiplin diri, percaya diri, tanggung jawab, dan kemampuan menggunakan akal sehat. yang tercermin dalam berpikir, berbicara, dan berperilaku yang sejalan dengan nilai-nilai karakter yang baik.

Kata kunci: modeling, pendidikan karakter, ideology five-on, perguruan tinggi

ABSTRACT-Moral decadence among students is quite alarming at this time because they are agents of change towards a better future. Change itself is something that is absolutely and definitely will happen. Thus, students are supposed to be the creator of the ideas presented in the form of thought which regularly and in accordance with the nature of science is based on the character as a result of the learning process on campus. However, a character-based learning alone will not guarantee moral improvement. As a result, the application required a strong foundation. Ideology five-I synergize and synchronize the existing energy among the students, the environment, and educators into energy learning in educational situations vibrant, effective, and efficient for improving human dignity. Model character education based on five-i is expected to improve the quality of learning, including good character which includes the student's motivation in learning, honesty, self-reliance, 
self-discipline, confidence, responsibility, and the ability to use common sense, which is reflected in thinking, speaking and behaving which is in line with the values of good character.

Keywords: modeling, character education, ideology five-on, college

\section{A. PENDAHULUAN}

Pendidikan karakter yang idealnya ditanamkan sejak dini di lembaga pendidikan dasar dan menengah, seharusnya lebih ditingkatkan pada jenjang pendidikan tinggi, sebab peserta didik di lingkungan kampus mempunyai kepentingan langsung dan praktis terhadap karakter-karakter positif, serta lebih dekat untuk terjun dalam kehidupan riil di masyarakat. Dengan demikian karakter-karakter positif bagi mahasiswa merupakan keniscayaan dan kebutuhan yang mendesak.

Mahasiswa merupakan agen suatu perubahan (agent of change) menuju arah yang lebih baik. Perubahan sendiri merupakan hal yang mutlak dan pasti akan terjadi. Bagi orang yang ingin maju, maka perubahan menjadi faktor utama. Pendidikan karakter bagi mahasiswa sebagai agen perubahan akan lebih baik apabila dalam penerapannya memiliki basis ideologi lima-I yang akan meningkatkan harkat dan martabat manusia (HMM).

Mengamati perkembangan pendidikan karakter di perguruan tinggi, dapat dikatakan bahwa pendidikan karakter di beberapa perguruan tinggi selama ini telah berjalan namun belum terprogram secara sistemik, sehingga tidak memiliki dampak signifikan secara nasional. Berbagai pengalaman yang dimiliki oleh berbagai perguruan tinggi di Indonesia dapat dijadikan acuan sebagai pengalaman baik (best practice) yang dapat diimplementasikan di perguruan tinggi masing-masing.

Model pendidikan karakter di perguruan tinggi di Indonesia terutama berkaitan dengan; (1) Bentuk-bentuk pelaksanaan pendidikan karakter yang sudah dilakukan oleh perguruan tinggi; (2) Perangkat yang diperlukan untuk implementasi pendidikan karakter di perguruan tinggi; (3) Model pelaksanaannya dalam konteks pembelajaran di perguruan tinggi; dan (4) Model pendidikan karakter yang efektif dan sesuai di perguruan tinggi terutama berkaitan dengan budaya anti menyontek dan plagiat.

Tujuan utama penelitian ini adalah untuk menyusun buku pedoman pendidikan karakter berbasis ideologi lima-i di perguruan tinggi sebagai penguatan mata kuliah civic education dan giat ekstrakurikuler kepramukaan untuk diimplementasikan yang memuat:

1. Pelaksanaan pendidikan karakter yang tepat untuk diterapkan di perguruan tinggi.

2. Perangkat yang diperlukan untuk implementasi pendidikan karakter di perguruan tinggi.

3. Model pendidikan karakter dalam konteks pembelajaran di perguruan tinggi.

4. Model pendidikan karakter yang efektif dan sesuai di perguruan tinggi.

\section{Pendidikan Karakter}

Pengertian Pendidikan Karakter menurut Kemendiknas (2011: 6) 
Pendidikan karakter adalah usaha menanamkan kebiasaan-kebiasaan yang baik (habituation) sehingga peserta didik mampu bersikap dan bertindak bersadarkan nilai-nilai yang telah menjadi kepribadiannya. Menurut Murphy (1998: 22) pendidikan karakter adalah pendidikan yang didasarkan pada nilai-nilai etika inti berakar dalam masyarakat demokratis, khususnya, penghar- gaan, tanggung jawab, kepercayaan, keadilan dan kejujuran, kepedulian, dan kemasyarakatan kebajikan dan kewarganegaraan. Lickona (1991) menambahkan pendidikan karakter adalah segala usaha yang dapat dilakukan untuk mempengaruhi karakter mahasiswa. Lebih jelas Lickona menyatakan bahwa pengertian pendidikan karakter adalah suatu usaha yang disengaja untuk membantu seseorang sehingga ia dapat memahami, memperhatikan, dan melakukan nilai-nilai etika yang sebenarnya. Hurlock (1993) menjelaskan bahwa perkembangan anak dipengaruhi oleh sekurang- kurangnya enam kondisi lingkungannya yaitu: hubungan antar pribadi yang menyenangkan, keadaan emosi, metode pengasuhan anak, peran dini yang diberikan kepada anak, struktur keluarga di masa kanak-kanak dan rangsangan terhadap lingkungan sekitarnya.

Dari uraian di atas dapat disimpulkan bahwa pendidikan karakter merupakan pendidikan nilai, pendidikan budi pekerti, pendidikan moral, pendidikan watak, yang bertujuan mengembangkan kemampuan peserta didik untuk memberikan keputusan baik-buruk, memelihara apa yang baik, mewujudkan dan menebar kebaikan itu dalam kehidupan sehari- hari dengan sepenuh hati.
BIP: Jurna Bahasa Indonesia Prima, Vol 3, No. 1, 2021, Maret 2021, pp. Tujuan dan Fungsi Pendidikan karakter

Menurut Kemendiknas (2011:2) Pendidikan karakter bertujuan mengembangkan nilai-nilai yang membentuk karakter bangsa yaitu Pancasila, meliputi: (1) mengembangkan potensi peserta didik agar menjadi manusia berhati baik, berpikiran baik, dan berprilaku baik; (2) membangun bangsa yang berkarakter Pancasila; mengembangkan potensi warganegara agar memiliki sikap percaya diri, bangga pada bangsa dan negaranya serta mencintai umat manusia. Ramli (2003) menambahkan bahwa pendidikan karakter memiliki esensi dan makna yang sama dengan pendidikan moral dan pendidikan akhlak. Tujuannya adalah membentuk pribadi anak, supaya menjadi manusia yang baik, warga masyarakat, dan warga Negara yang baik.

Dari penjelasan di atas maka dapat di artikan bahwa Pendidikan karakter pada intinya bertujuan membentuk bangsa yang tangguh, kompetitif, berakhlak mulia, bermoral, bertoleran, bergotong royong, berjiwa patriotik, berkembang dinamis, berorientasi ilmu pengetahuan dan teknologi. Sedangkan fungsi Pendidikan karakter menurut Kemendiknas $(2011,2)$ adalah (1) membangun kehidupan kebangsaan yang multikultural; (2) membangun peradaban bangsa yang cerdas, berbudaya luhur, dan mampu berkontribusi terhadap pengembangan kehidupan ummat manusia; mengembangkan potensi dasar agar berhati baik, berpikiran baik, dan berperilaku baik serta keteladanan baik; (3) membangun sikap warganegara yang cinta damai, kreatif, mandiri, dan mampu hidup berdampingan dengan bangsa lain dalam suatu harmoni. 
BIP: Jurna Bahasa Indonesia Prima,

Vol 3, No. 1, 2021, Maret 2021, pp.

Lickona, (1991) menjelaskan

Pendidikan karakter diperlukan guna membuat peserta didik menyadari pentingnya memahami nilai-nilai yang ada di masyarakat dengan beberapa alasan, di antaranya: (1) Banyaknya generasi muda saling melukai karena lemahnya kesadaran pada nilai-nilai moral, (2) Memberikan nilai-nilai moral pada generasi muda merupakan salah satu fungsi peradaban yang paling utama, (3) Peran sekolah sebagai pendidik karakter menjadi semakin penting ketika banyak anak-anak memperoleh sedikit pengajaran moral dari orangtua, masyarakat, atau lembaga keagamaan, (4) masih adanya nilai-nilai moral yang secara universal masih diterima seperti perhatian, kepercayaan, rasa hormat, dan tanggungjawab, (5) Demokrasi memiliki kebutuhan khusus untuk pendidikan moral karena demokrasi merupakan peraturan dari, untuk dan oleh masyarakat, (6) Tidak ada sesuatu sebagai pendidikan bebas nilai. Sekolah mengajarkan pendidikan bebas nilai. Sekolah mengajarkan nilai-nilai setiap hari melalui desain ataupun tanpa desain, (7) Komitmen pada pendidikan karakter penting manakala kita mau dan terus menjadi tenaga pendidik yang baik, dan (8) Pendidikan karakter yang efektif membuat sekolah lebih beradab, peduli pada masyarakat, dan mengacu pada performansi akademik yang meningkat. Kemudian Soetanto (2012) menambahkan bahwa nilai-nilai luhur yang terkandung di dalam penerapan pendidikan karakter adalah prilaku berkarakter yang secara koheren memancar dari:

a) Olah pikir, meliputi cerdas, kritis, kreatif, inovatif, ingin tahu, berfikir terbuka, produktif, berorientasi Ipteks dan reflektif. b) Olah hati, meliputi sikap jujur, beriman dan bertakwa, amanah, adil, bertanggung jawab, berempati, berani mengambil resiko, pantang menyerah, rela berkorban, dan berjiwa patriotic.

c) Olah raga, meliputi sikap tangguh, bersih dan sehat, disiplin, sportif, andal, berdaya tahan, bersahabat, kooperatif, determinatif, kompetiyamantif, ceria dan gigih.

d) Olah rasa dan karsa, meliputi sikap peduli, ramah, santun, rapi, nyaman, saling menghargai, toleran, suka menolong, gotong royong, nasionalis, kosmopolit, mengutamakan kepentingan umum, bangga menggunakan bahasa dan produk Indonesia, dinamis, kerja keras, dan beretos kerja.

Jadi secara garis besar dapat disimpulkan bahwa nilai-nilai yang terkandung dalam penerapan pendidikan karakter meliputi nilai-nilai luhur bangsa dan agama.

1. Model Implementasi Pendidikan Karakter

Menurut Suparno, dkk. (2002:42-44), ada empat model pendekatan penyampaian pendidikan karakter a) Model sebagai Mata Pelajaran Tersendiri (monolitik) b) Model Terintegrasi dalam Semua Bidang Studi. Pendekatan yang kedua dalam menyampaikan pendidikan karakter adalah disampaikan secara terintegrasi dalam setiap bidang pelajaran, dan oleh karena itu menjadi tanggunmg jawab semua guru (Washington, et.all, 2008). c) Model di Luar Pengajaran dan d) Model Gabungan

2. Penerapan Pendidikan Karakter di Kalangan Mahasiswa

Flexner dalam Syukri (2009) berpendapat bahwa perguruan tinggi 
BIP: Jurna Bahasa Indonesia Prima,

Vol 3, No. 1, 2021, Maret 2021, pp.

merupakan tempat pencarian ilmu pengetahuan, pemecahan berbagai masalah, tempat mengkritisi karya-karya yang dihasilkan, dan sebagai pusat pelatihan manusia. Jadi, mahasiswa dididik dan dilatih di perguruan tinggi agar menjadi manusia intelektual yang mempunyai daya nalar tinggi, analisa yang luas dan tajam, berilmu tinggi dan berprilaku terpuji.

Namun, penerapan pendidikan karakter dikalangan mahasiswa banyak menemui kendala, hal ini terlihat pada misi perguruan tinggi yang dijabarkan oleh Arthur dalam Syukri (2009) yaitu pengajaran, penelitian dan aplikasi ilmu pengetahuan, yang secara tersirat membentuk opini bahwa pembentukan karakter bukan tugas perguruan tinggi. Kemudian Schwartz (2000) menyatakan ada beberapa hal yang mengundang kekeliruan terkait penerapan pendidikan karakter dikalangan mahasiswa; 1) Karakter seseorang sudah terbentuk sebelum masuk ke perguruan tinggi dan merupakan tanggung jawab orang tua untuk membentuk karakter anaknya 2) Perguruan tinggi, khususnya dosen, tidak memiliki kepentingan dengan pembentukan karakter, karena mereka direkrut bukan untuk melakukan hal tersebut dan 3) Karakter merupakan istilah yang mengacu pada agama atau ideologi konservatif tertentu.

Dari penjelasan diatas dapat disimpulkan bahwa sebenarnya pendidikan karakter di perguruan tinggi dapat melengkapi dan menguatkan karakter yang sudah terbentuk pada diri mahasiswa yang didapat pada tingkat pendidikan sebelumnya. Penerapannya harus mempunyai strategi guna mencapai hasil yang diinginkan, Soetanto (2012) mengungkapkan bahwa ada beberapa strategi yang bisa digunakan dalam penerapan pendidikan karakter; 1) Melalui pembelajaran, 2) Melalui ekstrakulikuler dan 3) Melalui pengembangan budaya perguruan tinggi.

Pendidikan karakter hendaknya mencakup aspek pembentukan kepribadian yang memuat dimensi nilai-nilai kebajikan universal dan kesadaran kultural di mana norma-norma kehidupan itu tumbuh dan berkembang. Supaya pendidikan karakter mampu membuat kesadaran transendental individu mampu terejawantah dalam perilaku yang konstruktif berdasarkan konteks kehidupan di mana ia berada: Memiliki kesadaran global, namun mampu bertindak sesuai konteks lokal.

\section{Perpektif Pendidikan Karakter}

Pendidikan karakter sebagai sebuah program kurikuler telah dipraktekan di sejumlah negara. Studi J. Mark Halstead dan Monica J. Taylor (2000) menunjukkan bagaimana pembelajaran dan pengajaran nilai-nilai sebagai cara membentuk karakter terpuji telah dikembangkan di sekolah-sekolah di Inggris. Peran lembaga pendidikan yang menonjol terhadap pembentukan karakter berdasarkan nilainilai tersebut ialah dalam dua hal yaitu: to build on and supplement the values children have already begun to develop by offering further exposure to a range of values that are current in society (such as equal opportunities and respect for diversity); and to help children to reflect on, make sense of and apply their own developing values (Halstead dan Taylor, 2000: 169).

Untuk membangun dan melengkapi nilai-nilai yang telah dimiliki anak agar berkembang sebagaiamana nilai-nilai tersebut juga hidup dalam masyarakat, 
BIP: Jurna Bahasa Indonesia Prima, Vol 3, No. 1, 2021, Maret 2021, pp.

serta agar anak mampu merefleksikan, peka, dan mampu menerapkan nilai-nilai tersebut, maka pendidikan karakter tidak bisa berjalan sendirian. Dalam kasus di Inggris, review penelitian tentang pengajaran nilai-nilai selama dekade 1990an memperlihatkan bahwa pendidikan karakter yang diusung dengan kajian nilainilai dilakukan dengan program lintas kurikulum. Halstead dan Taylor (2000: 170-173) menemukan bahwa nilai-nilai yang diajarkan tersebut juga disajikan dalam pembelajaran Citizenship; Personal, Social and Health Education.

Model-model pendidikan karakter menurut jenjang usia yang dikaji dari berbagai hasil penelitian dapat dirumuskan kembali dalam berbagai macam tindakan pendidikan karakter.

Strategi Pendidikan Karakter menurut Jenjang Usia

(diadaptasi dari Character eduducation, guidance and lifesskills)

\begin{tabular}{|c|c|c|c|c|}
\hline \multirow{2}{*}{ No } & \multirow{2}{*}{ Karakter } & \multicolumn{3}{|c|}{ Strategi pendidikan karakter menurut usia } \\
\hline & & Anak-anak & Remaja & Dewasa \\
\hline 1 & $\begin{array}{l}\text { Trustwor } \\
\text { thiness }\end{array}$ & $\begin{array}{l}\text { Melatih anak untuk } \\
\text { menyampaikan pesan atau } \\
\text { titipan. }\end{array}$ & \begin{tabular}{|c|} 
Memberi tugas \\
memimpin kelompok
\end{tabular} & $\begin{array}{l}\text { Mendelegasikan } \\
\text { untukmengikuti } \\
\text { kompetisi } \\
\text { lomba }\end{array}$ \\
\hline 2 & Respect & \begin{tabular}{l|} 
Mengucap salam, \\
mencium tangan setiap \\
ketemu teman atau saudara
\end{tabular} & \begin{tabular}{|l|} 
Bersikap sopan \\
terutama kepada orang \\
yang lebih tua
\end{tabular} & $\begin{array}{l}\text { Mematuhi kode } \\
\text { etik pergaulan, }\end{array}$ \\
\hline 3 & $\begin{array}{l}\text { Responsi } \\
\text { bility }\end{array}$ & \begin{tabular}{|l|l|} 
Memberesi & alat bekas \\
mainannya & \\
Sendiri
\end{tabular} & $\begin{array}{l}\text { Memberi tugas } \\
\text { Piket kelas pekerjaan } \\
\text { rumah }\end{array}$ & \begin{tabular}{|l|} 
Memberi tugas \\
dengan batas \\
wakktu tertentu
\end{tabular} \\
\hline 4 & Fairness & \begin{tabular}{|l|} 
Membagi makanan \\
dengan jumlah yang sama \\
kepada saudarateman
\end{tabular} & $\begin{array}{l}\text { Membagi tugas } \\
\text { kelompok sesuai dengan } \\
\text { kemampuan }\end{array}$ & \begin{tabular}{|l|} 
Membagi tugas \\
kelompok \\
dengan kemampuai \\
\end{tabular} \\
\hline 5 & Caring & $\begin{array}{l}\text { Membolehkan alat } \\
\text { permaimannya dipinjam } \\
\text { teman } \\
\end{array}$ & $\begin{array}{l}\text { Membantu panti } \\
\text { asuhan, menolong teman }\end{array}$ & \begin{tabular}{|l} 
Menjadi relawan, \\
korps sukarela
\end{tabular} \\
\hline 6 & $\begin{array}{c}\text { Citten- } \\
\text { ship }\end{array}$ & \begin{tabular}{|l} 
Tidak berebut, \\
mengalah, sabar \\
menunggu giliran,
\end{tabular} & \begin{tabular}{|l} 
Mengikuti \\
upacara bendera atau \\
pramuka
\end{tabular} & $\begin{array}{l}\text { Mentaati } \\
\text { Peratu an, disisplim, }\end{array}$ \\
\hline 7 & Honesty & $\begin{array}{l}\text { Tidak boleh } \\
\text { mengambil barang milik } \\
\text { orang laim }\end{array}$ & \begin{tabular}{|l|} 
Mengembalikan \\
Barang yang \\
dipmjam/ditemu kan
\end{tabular} & \begin{tabular}{|l|} 
Tidak nyontek, \\
menyalin pekerjaan \\
teman \\
\end{tabular} \\
\hline 8 & Courage & $\begin{array}{l}\text { Mencoba berbagai } \\
\text { alat permainan yang } \\
\text { menantang, }\end{array}$ & $\begin{array}{l}\text { Mencobab berbagai olah } \\
\text { raga kegiatan yang } \\
\text { menantang }\end{array}$ & \begin{tabular}{|l} 
Memimpin \\
diskusi, memberi tugas \\
yang menan tang
\end{tabular} \\
\hline 9 & Diligence & $\begin{array}{l}\text { Bermain, menari, } \\
\text { membaca cerita bergambar } \\
\text { dengan jadwal yang rutin, }\end{array}$ & \begin{tabular}{|l|} 
Memperbanyak \\
aktivitas positif, \\
kegiatan ekstrakurikuler
\end{tabular} & $\begin{array}{l}\text { Memberi banyak } \\
\text { kegiatan positif, } \\
\text { penyaluran bakat }\end{array}$ \\
\hline 10 & Integrity & \begin{tabular}{|l|} 
Menceritakan \\
kembali apa yang telah \\
dialami
\end{tabular} & \begin{tabular}{|l|} 
Menjaga \\
Integritas diri sendiri
\end{tabular} & \begin{tabular}{|l|} 
Menjaga \\
integritas diri
\end{tabular} \\
\hline
\end{tabular}

Sesuai dengan tingkat perkembangan psikologi maka model pendidikan karakter pada usia anak-anak, remaja dan dewasa adalah sebagai berikut:

\begin{tabular}{|c|l|l|l|}
\hline No & \multicolumn{1}{|c|}{ Jenjang Usia } & $\begin{array}{l}\text { Tujuan Pendikan } \\
\text { karakter }\end{array}$ & \multicolumn{1}{|c|}{ Model Pendidikan Karakater } \\
\hline 1 & $\begin{array}{l}\text { Model pendidikan pada } \\
\text { anak-anak }\end{array}$ & $\begin{array}{l}\text { Membentuk } \\
\text { karakter }\end{array}$ & $\begin{array}{l}\text { Anak-anak masih dalam masa bermain, } \\
\text { oleh sebab itu model pendidikan } \\
\text { karakter yang efektif disampaikan } \\
\text { melalui kegiatan bermain peran, } \\
\text { bercerita, kantin kejujuran dan lainnya }\end{array}$ \\
\hline 2 & $\begin{array}{l}\text { Model pendidikan karakter } \\
\text { pada remaja }\end{array}$ & $\begin{array}{l}\text { mengembangkan } \\
\text { karakter } \\
\text { kepribadian }\end{array}$ & $\begin{array}{l}\text { Pendidikan karakter dilakukan dengan } \\
\text { tindak tutur direktif (nasehat, perintah, } \\
\text { anjuran, dsb). Model pendidikan } \\
\text { karakter pada remaja diintegrasikan } \\
\text { dalam berbagai kegiatan pembelajaran, } \\
\text { peraturan sekolah, dan kegiatan } \\
\text { ekstrakurikuler atau media poster yang } \\
\text { ditempel di dinding-dinding sekolah }\end{array}$ \\
\hline 3 & $\begin{array}{l}\text { Model pendidikan karakter } \\
\text { pada orang dewasa }\end{array}$ & $\begin{array}{l}\text { untuk pemantapan } \\
\text { karakter yang } \\
\text { sudah terbentuk }\end{array}$ & $\begin{array}{l}\text { Model pendidikan karakter dilakukan } \\
\text { melalui pengajian, seminar, penulisan } \\
\text { karya ilmiah dan evaluasi diri }\end{array}$ \\
\hline
\end{tabular}

\section{Idiologi Pembelajaran Lima-I}

Pengertian Ideologi dan Perkembangan Ideologi Pendidikan. Menurut bahasa (etimologi) kata "ideologi" berasal dari dua kata, yaitu: "idea" yang artinya pikiran dan "logos" yang artinya ilmu. Istilah ideologi bisa dimaknai dan mengandung pengertian berarti ilmu pengetahuan tentang ide-ide, tentang keyakinan atau tentang gagasan (Gazhali, 2004:43). Pengertian lainnya, ideologi adalah studi tentang gagasan, pengetahuan kolektif, pemahaman-pemahaman, pendapat- pendapat, nilai-nilai, prakonsepsi-prakonsepasi, pengalamanpengalaman dan atau ingatan informasi sebuah kebudayaan dan juga rakyat individual.

Secara umum dapat dikatakan bahwa, Ideologi sebagai sistem berfikir, sistem kepercayaan, praktik-praktik simbolik yang berhubungan dengan tindakan sosial dan politik (Thompson, 2007:17). Sementara filosuf Prancis Antoine Destult de Tracy (1754-1836) yang hidup pada masa Revolusi Prancis orang yang pertama sekali menemukan istilah "ideology" pada tahun 1796, mendifinisikan ideologi sebagai" ilmu tentang pikiran manusia (sama seperti biologi dan zologi yang merupakan ilmu tentang spesies) yang mampu menunjukan jalan yang benar menuju masa depan". 
Tilaar (2003:114) berpendapat ideologi merupakan sistem keyakinan yang dianut masyarakat untuk menata dirinya sendiri. Salah seorang pemikir posmodernis abad ke-20, Louis Althusser (1999) mengatakan bahwa ideologi merupakan sistem keyakinan yang menyembunyikan kontradiksi-kontradiksi internalnya. Artinya, dalam setiap ideologi disembunyikan kontradiksi-kontradiksi dalam ajaran-ajarannya. Misalnya, di dalam ajaran demokrasi liberal terdapat kelemahan-kelemahan yang merugikan sesama manusia dalam pemberian kesempatan untuk berkembang. Manusia yang gagal merupakan orang-orang yang tidak mampu mencapai kesuksesan dan bukan kontradiksi dalam sistem ekonomi itu sendiri. Foucault (dalam Tilaar, 2003:115) menyimpulkan bahwa ideologi menyangkut empat hal, yaitu; (a) ekonomi sebagai basisnya, (b) kelas yang berkuasa, (c) kekuasaan represif, dan (d) sesuatu yang berlawanan dengan kebenaran sejati.

Terry Eagleton salah seorang pakar yang mendalami tentang masalah ideologi dalam perkembangan dan aplikasinya pada kehidupan masyarakat, mengumpulkan berbagai definisi mengenai ideologi, sekali pun definisi ideologi tersebut masing-masing memiliki rumusan yang berbeda-beda satu dengan yang lain, bahkan tidak jarang bertentangan satu sama lainnya. Tidak kurang 15 definisi yang dikumpulkan oleh Eagleton. Diantara definisi itu adalah sebagai berikut; (a) ideologi sebagai proses produksi dari arti, lambang dan nilai-nilai dalam kehidupan sosial, (b) ideologi sebagai suatu kumpulan ide-ide yang merupakan karakteristik dari suatu kelompok sosial atau kelas, (c) ideologi merupakan ide-ide yang membantu untuk
BIP: Jurna Bahasa Indonesia Prima, Vol 3, No. 1, 2021, Maret 2021, pp. melegitimasikan kekuasaan politik yang dominan, (d) ideologi merupakan ide-ide palsu untuk melegitimasikan kekuasaan politik yang dominan, (e) ideologi merupakan bentukbentuk pemikiran yang dimotivasikan oleh kepentingankepentingan sosial, (f) ideologi adalah pemikiran identitas, (g) ideologi adalah ilusi sosial yang diperlukan, (h) ideologi merupakan perangkat pelaku-pelaku sosial untuk menentukan arti terhadap dunianya, (i) ideologi adalah merupakan suatu perangkat kepercayaan sebagai dasar bertindak, (j) ideologi sebagai perangkat yang diperlukan bagi seorang individu untuk hidup dalam hubungannya dengan struktur sosial (Tilaar, 2003: 115-116).

Beberapa definisi di atas, memberi makna pengertian ideologi sebagai kekuatan bagi kehidupan manusia dalam rangka menuntun dan membangun suatu peradaban yang unggul, dimana biasanya ideologi yang dilaksanakan oleh suatu masyarakat bersumber dari agama, moral, nilai-nilai, etika, ide-ide, pemikiran, adatistiadat maupun kebudayaan yang kuat dipegang teguh. Karena itu, ideologi selalu diasumsikan bekerja sebagai perekat hubungan sosial yang mengikat anggota masyarakat secara bersama-sama dengan menetapkan nilai-nilai dan norma-norma yang disepakai secara kolektif.

Pemikiran Prayitno

(2009:491) memberi pengertian tentang ideologi merupakan dasar pegangan yang sangat kuat terkait dengan ide, teori ataupun sistem yang diakui kebenarannya, diikuti serta diperjuangkan dan dilaksanakan dalam praktek, dengan komitmen, dedikasi dan tanggung jawab yang setinggitingginya, kalau perlu dengan pengorbanan apapun juga. 
Dalam konteks dunia pendidikan, Menurut Tilaar (2003: 17) ada beberapa hal yang berkaitan dengan pengertian ideologi yang mempengaruhi praksis pendidikan, diantaranya pengertian ideologi sebagai ide-ide yang menentukan kehidupan dalam masyarakat (guiding principles). Sering kali kita mendengar bahwa masyarakat kita adalah masyarakat yang bermoral. Moral adalah susunan nilai-nilai atau idei-ide yang diagungkan dalam kehidupan bersama. Moral atau ide-ide dasar dapat bersumber dari agama, adat-istiadat, atau kebudayaan pada umumnya. Ide dapat juga diartikan sebagai suatu dokterin.

\section{Ideologi-Ideologi Pendidikan}

Perkembangan ideologi pendidikan dalam dunia pendidikan saat ini, tidak terlepas dari pemikiran tokoh-tokoh seperti William F. O’Neil dan Faulo Freire yang mencoba meramu beberapa pemikiran tokoh-tokoh sebelumnya yang bergerak pada tataran filsafat dan logika yang kemudian memasukkan ide-ide sebagai konsep berfilsafat, yang kemudian melahirkan konsep ideologi sebagai bagian disiplim ilmu baru. Misalnya Soeharto (2010) mengutip pendapat O'Neil, membagi ideologi pendidikan menjadi 2 (dua) kelompok besar, yaitu; pertama ideologi konservatif yang meliputi ideologi pendidikan fundamentalisme, ideologi pendidikan intelektualisme dan ideologi pendidikan konservatisme. Kedua, ideologi liberal yang meliputi ideologi pendidikan liberalisme, ideologi pendidikan liberasionisme, dan ideologi pendidikan anarkisme. Sementara, Freire (2003) dalam pemaparan dan pembahasan secara umum, memetakan ideologi pendidikan tersebut berdasarkan klasifikasi yang dikembangkan O’Neil ada 6 (enam)
BIP: Jurna Bahasa Indonesia Prima, Vol 3, No. 1, 2021, Maret 2021, pp. model ideologi pendidikan, sebagai berikut yaitu: 1) Ideologi Pendidikan Fundamentalisme 2) Ideologi Pendidikan Intelektualisme 3) Ideologi Pendidikan Konservatisme 4) Ideologi Pendidikan Liberal oleh John Dewey (O’Neill, 202: 356). 5) Ideologi Pendidikan Liberasionisme diwakili Paulo Freire, Niel Postman (O’Neil, 2002:466). 6) Ideologi Pendidikan Anarkisme 7) Ideologi Lima-i sebagai ideologi Pembelajaran

Menurut Prayitno (2009) ideologi limai merupakan inti dari harkat dan martabat manusia (HMM) dan lima-i perlu diwujudkan dalam diri dan kehidupan individu, tidaklah berlebihan kiranya limai dijadikan ideologi bagi dosen dan mahasiswa yang melandasi tugas dan tanggungjawabnya. Dengan ideologi itu pendidik mengimplementasikan proses pembelajaran untuk pengembangan potensi peserta didik secara optimal, yang tidak lain adalah perwujudan HMM pada diri dan kehidupan peserta didik. Ideologi lima-i dikuasai oleh dosen dan mahasiswa sebagai landasan energi baginya untuk melaksanakan proses pembelajaran secara taat azas dan berhasil. Secara operasional, ideologi pembelajaran diaktualisasikan melalui kewibawaan dan kewiyataan.

Penerapan ideologi lima-i mensinergikan dan mensinkronisasikan energi-energi yang ada pada peserta didik, lingkungan dan pendidik menjadi energi pembelajaran dalam situasi pendidikan yang bersemangat, efektif dan efesien.

Konsep ideologi dalam konteks pendidikan yang dimaksud adalah ideologi lima-i, yang terdiri, yaitu: (a) iman dan taqwa: meliputi segenap aspek Ketuhanan Yang Maha Esa dan perikehidupan keberagamaan, (b) inisiatif: berarti semangat, kemauan untuk memulai dan 
BIP: Jurna Bahasa Indonesia Prima,

Vol 3, No. 1, 2021, Maret 2021, pp.

mencoba, berdaya upaya, pantang menyerah, mencapai sesuatu hasil yang berguna,(c) industrius: meliputi, kerja keras, tekun, disiplin,pertimbangan efesien- ekonomi, nilai tambah dan jujur, (d) individu: mencakup kualitas potensi, kedirian individu dan kemandirian beserta perbedaan antara individu, (e) intraksi: mengandung makna keterkaitan individu satu dengan individu lainnya.(Prayitno, 2009:489).

Unsur-unsur lima-i saling terkait, saling mengisi, dan saling memperkuat serta bersama-sama mewakili seluruh unsur HMM.

Ideologi pembelajaran Lima-i dalam

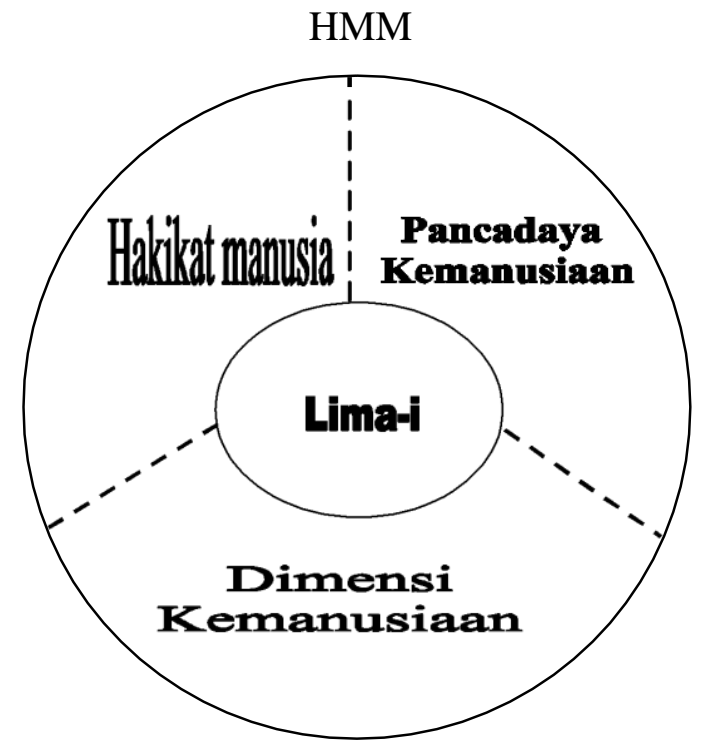

Pada diagram gambar diatas, memperlihatkan bahwa ideologi lima-i merupakan inti dari Harkat dan Martabat Manusia (HMM). Dalam pemahaman seperti itu, kelima unsur lima-i pada dasarnya dapat mewakili keseluruhan unsur HMM, dari sisi hakikat kemanusiaannya, dimensi kemanusiaannya, dan panca daya kemanusiaannya. Dengan demikian, apabila seseorang memiliki "jiwa lima-i" pada dirinya dan berperilaku serta menjalani kehidupannya dengan menuruti kaidah-kaidah lima-i, sesungguhnya pada diri orang itu telah terwujudkan HMM dalam sosok kediriannya dan dalam kehidupannya.

Dengan kata lain, seluruh komponen proses pembelajaran dijiwai oleh niai-nilai lima-i. Ideologi lima-i menjadi roh penyelenggaraan proses pembelajaran. Penjiwaan lima-i dalam proses pembelajaran digambarkan melalui diagram berikut ini:

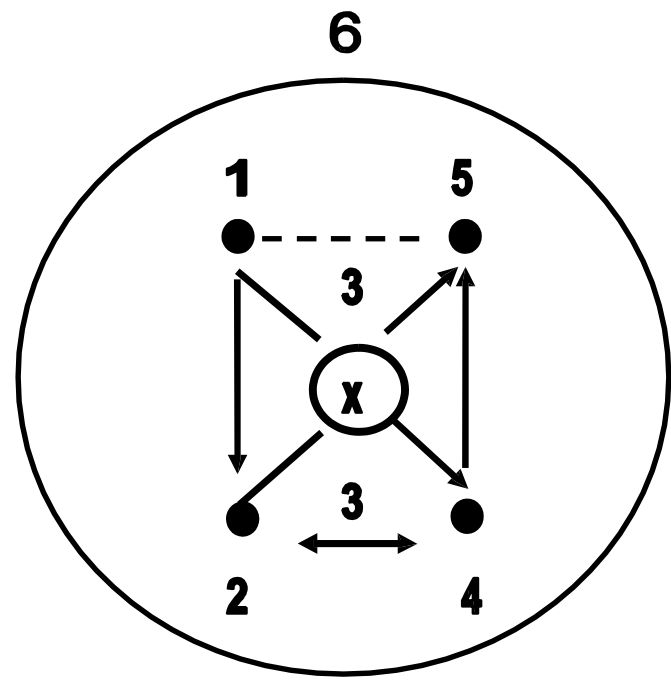

diadaptasi dari konsep dan pemikiran Prayitno, 2009

Keterangan:

1) Pendidik 2) Kewibawaan 3) Tujuan dan materi pembelajaran 4) Kewiyataan 5) Peserta didik dan 6) Ideologi lima-i, lingkaran yang membingkai seluruh unsur proses pembelajaran, menjiwai pendidik dalam mewujudkan kewibawaan dan kewiyataan, menjiwai tujuan dan materi pembelajaran, serta "membangun jiwa" peserta didik untuk berlima-i.

\section{Hubungan Pendidikan Karakter dengan Ideologi Pembelajaran Lima-I}

Pusat Kurikulum Depdiknas (2010) menyatakan bahwa dalam rangka lebih memperkuat pelaksanaan pendidikan karakter pada satuan pendidikan telah teridentifikasi 18 nilai yang bersumber dari agama, Pancasila, budaya, dan 
BIP: Jurna Bahasa Indonesia Prima,

Vol 3, No. 1, 2021, Maret 2021, pp.

tujuan pendidikan nasional, yaitu; Religius, Jujur, Toleransi, Disiplin, Kerja keras, Kreatif, Mandiri, Demokratis, Rasa Ingin Tahu, Semangat Kebangsaan, Cinta Tanah Air, Menghargai Prestasi, Bersahabat/ Komunikatif, Cinta Damai, Gemar Membaca, Peduli Lingkungan, Peduli Sosial dan Tanggung Jawab.

Konsep ideologi dalam konteks pendidikan yang dikembangkan pada penelitian ini adalah ideologi pembelajaran lima-i, yang terdiri, yaitu:

a) iman dan taqwa; meliputi segenap aspek Ketuhanan Yang Maha Esa dan perikehidupan keberagamaan,

b) inisiatif; berarti semangat, kemauan untuk memulai dan mencoba, berdaya upaya, pantang menyerah, mencapai sesuatu hasil yang berguna,

c) industrius; meliputi, kerja keras, tekun, disiplin, pertimbangan efesienekonomi, nilai tambah dan jujur,

d) individu; mencakup kualitas potensi, kedirian individu dan kemandirian beserta perbedaan antara individu,

e) intraksi; mengandung makna keterkaitan individu satu dengan individu lainnya.

Amri, Jauhari, \& Elisah (2011: 32); Mulyasa (2013: 10); dan Samani \& Hariyanto (2013: 29-30) menyatakan bahwa keberhasilan program pendidikan karakter dapat diketahui melalui pencapaian indikator oleh peserta didik sebagaimana tercantum dalam standar lulusan disetiap lembaga pendidikan yang meliputi; mengamalkan ajaran agama yang dianut sesuai dengn tahapan perkembangan manusia, memahami kekurangan dan kelebihan diri sendiri, menunjukkan sikap percaya diri, mematuhi aturan-aturan sosial yang berlaku dalam lingkungan yang lebih luas, menghargai keberagaman agama, budaya, suku, ras, dan golongna sosial ekonomi dalam linkup nasional, mencari dan menerapkan informasi dari lingkungan sekitar dan sumber-sumber lain secara, logis, kritis dan kreatif, menunjukkan kemampuan berfikir logis, kritis, kreatif, dan inovatif, menunjukkan kemampuan belajar secara mandiri sesuai dengan potensi yang dimilikinya, menunjukkan kemampuan menganalisis dan memecahkan masalah dalam kehidupan sehari-hari, mendeskripsikan gejala alam dan sosial, memanfaatkan lingkungan secara bertanggung jawab, menerapkan nilai-nilai kebersamaan dalam kehidupan bermasyarat, berbangsa, dan bernegara, menghargai karya seni dan budaya, menghargai tugas pekerjaan dan memiliki kemampuan untuk berkarya, menerapkan hidup bersih, sehat, bugar, aman, dan memanfaatkan waktu luang secara baik, berkomunikasi dan berinteraksi secara efektif dan santun, memahami hak dan kewajiban diri dan orang lain dalam pergaulan di masyarakat, menghargai fakta berbeda pendapat, menunjukkan kegemaran membaca dan menulis naskah, menunjukkan keterampilan menyimak, berbicara, membaca, dan menulis, menguasai pengetahuan yang diperlukan untuk studi lanjutan; dan memiliki jiwa wirasuaha. 
Hasil pendidikan Karakter berbasis lima-I yang diharapkan

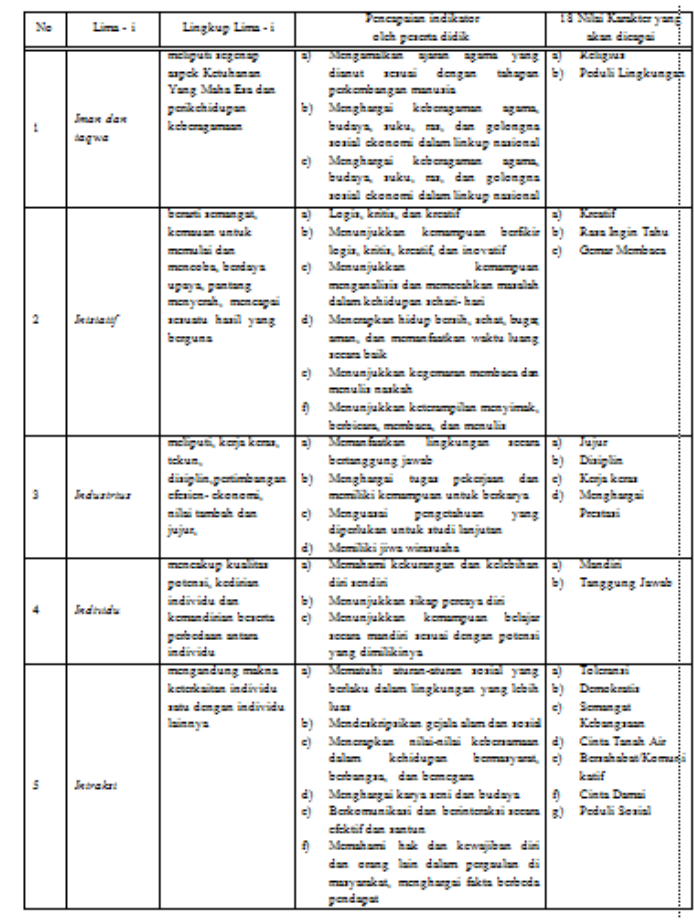

\section{B. SIMPULAN}

Pendidikan karakter merupakan pendidikan nilai, pendidikan budi pekerti, pendidikan moral, pendidikan watak, yang bertujuan mengembangkan kemampuan peserta didik untuk memberikan keputusan baik-buruk, memelihara apa yang baik, mewujudkan dan menebar kebaikan itu dalam kehidupan sehari-hari dengan sepenuh hati.

Membentuk karakter mahasiswa yang baik adalah menjadi salah satu misi dan tanggung jawab dari pendidikan karakter di perguruan tinggi. Oleh karena itu, pendidikan karakter di perguruan tinggi saat ini menjadi isu yang semakin menarik untuk dilaksanakan, sebagai upaya menyiapkan generasi penerus yang mampu menghadapi tantangan global yang semakin kompleks. Salah satu model pendidikan karakter yang dapat diterapkan di perguruan tinggi adalah dengan menerapkan pendidikan karakter berbasis ideologi lima-i dalam proses pembelajaran
BIP: Jurna Bahasa Indonesia Prima,

Vol 3, No. 1, 2021, Maret 2021, pp. maupun dalam kegiatan ekstrakurikuler di perguruan tinggi.

\section{DAFTAR PUSTAKA}

Character Education Partnership. 2003. Character Education Quality Standards. Washington: Character Education Partnership

Cholisin. 2004. "Konsolidasi Demokrasi Melalui Pengembangan Karakter Kewarganegaraan," Jurnal Civics, Vol. 1, No. 1, Juni, pp. 14-28

Freire, Paulo dkk. 2003. Menggugat Pendidikan. Yogyakarta : Pustaka Pelajar.

Kemendiknas. 2011. Panduan Pendidikan Karakter. Jakarta: Pusat Kurikulum dan Kebukuan Kemendiknas.

Kirschenbaum, Howard. 2000). From Values Clarification to Character Education: A Personal Journey. The Journal of Humanistic Counseling, Education and Development. Vol. 39, No. 1, September, pp. 4-20.

Lickona, Thomas. 1991. Educating for character: How our schools can teach respect and responsibility. New York: Bantam Books.

Murphy, M.M. 1998. Character Education in America's Blue Ribbon Schools. Lancaster PA, Technomic.

Mazzola, J. W. 2003. Bullying in school: a strategic solution. Washington, DC: Character Education Partnership.

O'neil, F. William. 2002. Ideologi-Ideologi Pendidikan (alih bahasa Omin Intan Naomi). Yogyakarta: Pustaka Pelajar. 
Pusat Bahasa Depdiknas. 2008. Kamus Bahasa Indonesia. Jakarta: Departemen Pendidikan Nasional.

Pusat Kurikulum Depdiknas. 2010. Bahan Pelatihan Penguatan Metodologi Pembelajaran Berdasarkan Nilai-nilai Budaya untuk Membentuk Daya Saing dan Karakter Bangsa, Jakarta: Kemendiknas.

Prayitno. 2009. Pendidikan Dasar Teori dan Praksis (jilid I dan II) Padang: Universitas Negeri Padang Press.

Suparno, Paul, Moerti Yoedho K., Detty Titisari, St. Kartono. 2002. Pendidikan Budi Pekerti di Sekolah. Yogyakarta: Kanisius.

Schwartz, AJ. 2000. It's Not to Late to Teach College Student about Values. The Chronicle of Higher Education. Vol 46. No 40.pg A68

Soetanto, Hendrawan. 2012. Pendidikan Karakter. Malang; Univ. Brawijaya

Syukri Fathudin. 2010. Pembentukan Kultur Akhlak Mulia Melalui Pembelajaran
BIP: Jurna Bahasa Indonesia Prima, Vol 3, No. 1, 2021, Maret 2021, pp. Pendidikan Agama Islam dengan Model Penilaian Self-And Peer Assesment pada Kalangan Mahasiswa Fakultas Teknik UNY. Laporan Penelitian FT UNY.

Tilaar. H.A.R. 2002. Perubahan Sosial dan Pendidikan Pengantar Pedagogik Transformatif untuk Indonesia.Jakarta: Gremedia.

Tilaar. H.A.R. 2003. Kekuasaan dan Pendidikan Suatu Tinjauan dar Perspektif Studi Kultural. Magelang: Indonesia Tera.

Thomson, B. John. 2007. Analisis Ideologi Kritik Wacana Ideologi-ideologi Dunia. (Penerjemah Haqqul Yaqin). Yog

Williams, Mary M. 2000. Models of Character Education: Perspectives and Developmental Issues. The Journal of Humanistic Counseling, Education and Development. Vol. 39, No. 1, September, pp. 32-40. 